\title{
The Program Development of Guidance And Counseling Based on Community at Semarang-Indonesia
}

\author{
Sugiyo $^{a}$, Mulawarman ${ }^{b}$, Muslikah $^{c}$, Abdul Kholiq $^{\mathrm{d}}$ \\ Department Guidance and Counseling, Faculty of Education, Universitas Negeri Semarang \\ Semarang, Indonesia
}

Corresponding e-mail: sugiyo@mail.unnes.id

\begin{abstract}
Nowadays, there are some social issues such as drugs abuse, LGBT, prostitutes, and street children which need the counseling services in the realm outside the school. The objective of the research was specifically to develop a Guidance and Counseling (GC) program based on Community. It was a research and development research. The data were collected by distributing questionnaires, conducting interviews and Focus Group Discussions (FGDs) involving community counselors and beneficiaries of community at Semarang. Based on the result of the research, it can be concluded that the model of GC program at the community as the GC service outside school was needed by the community counselor. The stages of the research were the preliminary study, the formulation and development of the program model of GC based on community, the experts' and the practitioners' validation through FGDs, program improvement and development. Thus, it is expected that the program model development of GC based on community was ready to be used for improving the service quality of GC at communities. Then, it is suggested: 1) for the researchers to describe the operational research stages in detailed so the model is more applicable and easy to be understood, 2) for community counselors to develop a GC Program based on Community which is appropriate to the needs for providing the optimum GC services.
\end{abstract}

Keywords: $\quad$ program, guidance and counseling (GC), community

\section{INTRODUCTION}

Counseling and Guidance (GC) management was conducted in the stages of programming, program implementation and evaluation [1],[2],[3],[4],[5]. The preparation of the program began with the need assessment, and then preceded it with the planning of counseling guidance activities to meet those needs [2]. The program implementation was done by implementing the counseling and guidance services.

The whole process of counseling and guidance management must be accompanied by accountability enforcement. Since accountability had a very important role in guidance and counseling services at schools [6],[7],[8],[9]. Cobia and Handerson explained that accountability was a counselor's effort to show users and stakeholders what they have done to improve students' academic success. Accountability enforcement was done if the counselor conducted the evaluation of counseling program he/ she has implemented [1],[8]. Based on the evaluation results, the counselor could assess the effectiveness of counseling guidance program which has been implemented. Furthermore, the evaluation results were presented to the community as a form of accountability.

Nowadays, counseling and guidance services were still widely developed in the school programs. On the other hand, the need assessment and Guidance and Counseling (GC) programs outside schools such as social community and rehabilitation settings have not been developed yet. Sugiyo's study on counselor performance at the program evaluation showed that the counseling program made by counselor tended to be made once and used for several years. The counseling programs were conducted without any evaluation of their weaknesses or relevance to the needs. And there is not any counseling services programs outside the school [10].

The success of the guidance counseling program was not only influenced by the good planning, since there were many variables or conditions which could be the success factors at the guidance program. Therefore, the need assessment and the development of GC program based on community were very important. Through the development of communitybased programs, the existence of guidance and counseling services would be more widely perceived by the wider community.

The implications of the above reality are the need for developing GC program based on community which allowed the counselor to provide the wider GC services; it was not only at schools but also at communities. This research was specifically directed to develop a GC Program based on Community at Semarang. Through the development of community-based programs, it was desirable to know the needs and problems outside the school, a GC Program based on Community which could be utilized by the community counselors, which in turn could contribute to the performance improvement.

It was a very important research because there were few researches which developed the GC 
program outside the school. Only a few experts attempted to design the research to assess the effectiveness of comprehensive counseling programs [11]. The researches on the impact of counseling services were used to conduct the experimental strategy, consequently; the understanding of the services impact focused on a single service. Though; the practice needs of counseling services outside the school were more urgent and needed. It also happened in Indonesia; where there were few researches were specifically directed to create the guidance and counseling program based on community.

Therefore; this research was very important to be implemented and it was appropriate to the strategic plan of Semarang State University in producing innovation of quality education and character in the form of GC program development outside the school. The result of this study was expected to be a problem solving for counselors in carrying out the guidance and counseling services outside school or community settings. The guidance and counseling program based on community developed in this study was expected to encourage counselors to uphold the accountability of guidance and counseling services. Thus, counselors could show customers and stakeholders about the counselor's performance and benefits for counselees outside the school or community.

\section{METHODOLOGY}

The research was focused on developing the guidance and counseling program based on community. It was a research and development research [12]. The hypothetical design of the guidance and counseling program based on community was developed based on the need assessment of GC at the community. The expert valuation technique was used to validate the hypothetical instrument design. There were at least two groups of validating the program; first, the expert group and second, the social workers at Semarang.

The data were collected by questionnaires, FGDs, and interviews. There were two types of data of this study; quantitative and qualitative data. Quantitative data were from questionnaires which were analyzed by using descriptive statistical techniques through percentage analysis. Whereas; qualitative data were analyzed by interactive analysis which included four (4) stages: data collection, data reduction, data display, and inferences (Mills and Hubermen, 1984)

\section{RESULTS AND DISCUSSION}

\subsection{The Results of the Study}

The Analysis Results of the Preliminary Study through Interviews in Rumah Damai (Peace House) Community at Gunungpati, Semarang

Rumah Damai was one of the drug rehabilitation foundations located in Semarang. In the implementation of the program, there was not any guidance and counseling program. The management of Rumah Damai usually learnt about counseling independently through the special trainings but there was not any guidance and counseling program. The programs of Rumah Damai focused on spiritual activities since this rehabilitation was owned by a Christian foundation.

The implementation techniques of the programs were more into spiritual activities; such as reading the holy book, going worship to the church and other spiritual activities. The obstacles the implementation were the existence of self-rejection to the environment and the time management for students. To overcome those obstacles; it needed a program which giving understanding and appropriate communication for students for accepting the reality. The support systems of Rumah Damai were mentors, social workers, church practitioners and priests. The social workers helped them by giving lectures, counseling assistance and health assistance; such as checking students' blood and cholesterol at Rumah Damai routinely.

The existing programs at Rumah Damai were in line with the vision of the mission of Rumah Damai. The objective of Rumah Damai itself was to make students comfortable, considered and respected each other. The programs at Rumah Damai were morning reflection, morning meeting, spiritual activities, and more prayer activities. There was job description and division; such as mentors should do the mentoring, the counseling, the initial need assessment, and the final assessment which should be reported to the family. The reports should be accountable to the foundation. In other words, if there were bad reports development of students, then the responsibility was handled by the mentor. Before making the program, an assessment was conducted using the ASI Assessment of the International Assessment Association, which was simplified by the Ministry of Social Affairs.

It was a full time working at Rumah Damai. Mentors only had 10 hours off in a week, except for the social workers; they worked 7.5 working hours per week. For now, the ability required by a mentor or a coach was the intention from the bottom of his/ her heart. In addition, the capabilities gained here were from trainings conducted by National Narcotics Agency and Ministries. There were seven mentors; one mentor handled two chambers (eight students), 
and there were three social workers which were in charge of administration and minutes at Rumah Damai. There was a mentor meeting and coach per week in which the mentor created his own program according to the approval of another mentor. The programs were not only adapted to the trainings and education but they were also in line with students' needs at Rumah Damai which already had LCD and other facilities.

In the GC conceptual model, it was explained that at the planning stage, it all started from the assessment. Because the focus was on attitude changes; the assessment was used as the medical record for being the reference which should be handled first, for example; the family problem or the addiction problem. From the religious view, the planning stage was conducted by doing guidance, sharing and teaching students to pray. The observation showed that students were used to praying. At the stage of implementation, it was adjusted to the level of students' spirituality, for the most spiritual student could be the idol for all, whereas; for beginners, they just needed to know and care each others. As for the evaluation, it can be seen on their daily activities, by assessing students' changes in terms of their spirituality, because they were monitored 24 hours at Rumah Damai.

In terms of economics; the planning was done through the talent assessment, which students were asked their talents and interests in the field of economics; e.g. the student who was interested in economic then he was directed in the field of trade and so forth. For the implementation, students' skills and abilities were fitted to their talents and interests. For evaluation, at the end of the program, the mentor asked students whether they were steady with their choices or not.

In terms of sexual identity; in the planning, the family could visit Rumah Damai each three months. So the family could gather and meet with the wife and children. Even, for students who were already married, they could meet less than three months. In the evaluation, the mentor usually asked the family related to the changes or developments experienced by the student. After being monitored by the family, the family would report the student's changes during the student were with them. If the student did not change, so the family could not visit him for a period of time. Then, for students who have been rehabilitated for more than six months, they could meet their family for three days outside.

In the planning process of lifestyle; from the beginning, students were told some rules at Rumah Damai. Then, the students' rights were taken, which they were not allowed to communicate and hold HP, and students must follow all rules at Rumah Damai. For practicing the daily life, students were told that there would be time for them to communicate with parents. Whereas; when students were sick with flu for example, students would not be directly given drugs; it was for educating them to be stronger by teaching them not to forget to pray and be independent. In the evaluation, the mentor asked the family whether there were any changes or not. The family assessment was related to the changes of the student himself.

In terms of trauma, the planning was done by reinforcing the students' faith by remembering the God, teaching students to accept the reality of the life they were currently passing. In the implementation, it was done with the prevention programs; there were some addiction materials and giving understanding to them. In terms of physical activity, there were sports activities which kept them busy at Rumah Damai. For the evaluation, it was done by communicating to the family when the student was out of rehabilitation, it needed an answer to know whether any improvement either from the family or the student himself by seeing how percent of the student was recovering from his trauma.

In activities or programs based on the family life, sometimes students were still traumatized and reluctant to return to the environment. The mentor usually gave understanding to the family that the students should not be accused when returning to the family, and providing understanding to the family by placing trust for the students. Furthermore; Rumah Damai provided vocation or field trip to the tourism places or picnic to make them excited. In addition, the management also invited the leader of the room to go shopping monthly and occasionally invited students to eat out. Then, students were also invited to have regular church services every week. From those activities, the evaluation was done at the end of the program by conducting the final assessment.

Rumah Damai usually held individual and groups counseling once a week, in which for group counseling, it was conducted maximum of 8 people and led by one mentor. Students who experienced the activities at Oikoumene Christian Church (GKO), their activities began with spiritual activities, physical activities, and household activities such as washing the clothes, cleaning the floor as they could experience the changes slowly.

The budget for the activities or programs came from students' payments, and usually supported by the church and the owner of this foundation. According to the mentor, rehabilitation foundation needed GC program development, because the mentors were still less skillful in terms of theory and practice about counseling. The GC program which was expected by the management was individual counseling which was the next step therapy, then, students/ clients had the coping skills and their own ability. Furthermore, the GC program was expected to be more intensive because students at Rumah Damai needed the full time for recovery. 


\section{The Analysis Results of Preliminary Study through Interviews at Graha Mitra Community, Semarang}

From the results of interview with the director of NGO, Graha Mitra; it showed that the counseling program was to prevent and deal with AIDS disease. The NGO was collaborated with the Health Office of Semarang. The counseling carried out for the client was to be ready performing HIV testing and the follow-up counseling after the testing. The activities had been carried out by Non-Governmental Organization (NGO) Graha Mitra since 2006. The volunteers who performed the counseling already had the guidance book from Graha Mitra management.

The counseling was directed at the high-risk communities, but they were not HIV-infected yet. The activities were also supported by outreach activities where the NGO team went down to the high risk places and shared with their respective tasks. The guidance places were the NGO's partners which usually were not only the antisocial communities but also the general public having high risk of HIV-infected. In outreach activities, they also conducted assessments by approaching them in an unstructured interview. After getting the needs, they started performing the services and coaching to the beneficiaries. But it was difficult implementation of coaching process when the beneficiaries were unwilling to commit joining HIV counseling programs especially after the test. Thus; it needed some approaches to give them counseling.

But up to now, the counseling implementation was still relevant to do because it was still necessary to people who were at HIV-high risked understand the importance of HIV testing. There were only six officers of Graha Mitra; but there were also on-call officers if they were required. But all officers were directly involved in the process of making and implementing the program.

There were many programs for them. The programs were not always religious but they were expected to lead them believe that God was always there to help them. Then; for the economic activities, there were some economic modifications based on their needs and interests; such as catfish farms, salon training, and laundry, etc. All genders; men, women, and even transgender were accepted to join the NGO activities. In the neighborhood, we also did the programs by detecting high-risk environments but we did not cluster them.

From the interview results, it showed that the NGO was managed by self-funding and the funds were still not sufficient to finance all programs at Graha Mitra, but they did the best to implement all programs well.

The evaluation result conducted by NGO Graha Mitra showed that all programs had been implemented $100 \%$; they were outreach, and socialization, but some programs were not optimum; such as the HIV counseling program, the economic program, and etc. It was expected that in the future, the NGO provided programs which were suitable to each community which would be treated.

\section{The Model Development Of Gc Based On Community}

Based on the preliminary study conducted at Rumah Damai (Community of drug rehabilitation) and Graha Mitra (Community of prostitutes and HIV-AIDS sufferer rehabilitation), the prototype of model development consisted of:

(A) Rationale; (B) Objectives; (C) Goals and Targets of Development Program; (D) Content; (E) System support. The GC Program based on Community was located at both Rumah Damai and Graha Mitra where the program plan was implemented based on adjustments to real conditions. The overview of the program design can be seen at the appendix.

The design validation was the activity process to assess whether the product design could be used and produced more effective, efficient, and rational results. In the validation phase of the hypothetical model design, the researcher conducted the expert test or judgment which was done with two (2) experts on guidance and counseling service and two (2) community practitioners. The assessment result showed that generally, the development program was feasible and at good category. After validating, the researchers made revisions. For more details, the sheet of validation model can be seen in appendix 9 . Here were the description results of validity and feasibility tests of the experts.

The first expert was Kusnarto Kurniawan, $M . P d$, Kons. He was the expert on guidance and counseling. The average result of the feasibility test conducted by expert 1 was at very good criteria. The criteria indicated that the instruments which had been compiled were representative and feasible to be implemented.

The second expert was Sunawan, S.Pd, M.Si, Ph.D. He was also an expert on guidance and counseling. The average result of the feasibility test conducted by expert 2 was at good criteria. He viewed that the model should be improved at: (1) the GC Program based on community should be made more specific and unique comparing to the GC program at schools, (2) the GC program should be equipped with the program table to facilitate the practitioners, (3) and check and recheck the diction so it was easy to be understood.

After getting input from the experts, the research team immediately revised the instrument so it was ready to be validated by community practitioners. The practitioners' validation was performed prior to the instrument tryout, so its readability and feasibility could be measured and implemented.

\subsection{Discussion}


The results of this study presented an interesting need portrait for developing a GC program based on community because the mentor needed skills in terms of theory and practice of counseling. The GC program was expected to be the individual counseling which was the next step therapy for the clients, so clients had the coping skills and independent ability. Furthermore; the GC program was expected to be more intensive because students at Rumah Damai needed the full time for recovery.

Based on those findings, the perspective of the community counseling framework stated that when the counselor set up a counseling program on the community setting, the program should accommodate the diversity and adapted to the social context in which the community existed. It was also suggested that the community counselors always dealt with diverse populations and many human types and traits. The findings at Rumah Damai community showed that the management of rehabilitation program was incorporating the values of religiosity to the individual. In this case, the findings were suited to the study of individual ways for identifying himself towards the religion or belief, which they would generally believe in extraordinary experiences that beyond the boundaries of modern, empirical, and psychological Western views.

Meanwhile, based on the findings at Graha Mitra community, the management of community proposed a GC program by including the values of RESPECTFUL especially from the economic background and sexual identity. In other words, the program should be based on the behavior, values, views and attitudes of a person influenced by their economic class background and relate to his/ her gender identity.

Then, the community counselors/ mentors expected the training and instruments of the GC program based on community. It indicated that the development model of the GC program based on community was needed at community settings. The awareness of community counselors on the importance of GC programs based on community was a potential acceptance of the development GC program based on community.

The results of this study presented the program development of GC based on communities; i.e. the community of drug addiction and the community of prostitutes, HIV, and AIDS. The experts and practitioners stated that the model development was appropriate, clear, effective, but it needed to add various supports; such as tables or flowcharts to support the GC program based on community. Moreover, the experts stated that the program needed to improve the community counselors' competence and to add the uniqueness of the GC program comparing to the GC at schools. In order to carry out the program and evaluation of $\mathrm{GC}$, it required the adequate understanding of evaluation techniques and procedures, supporting instruments, and various facilities [2]. Therefore, the instruments were developed to support the activities which were appropriate with the services performed.

It was in line with the above conditions, the practitioners/ counselors were looking for trainings on the implementation of a GC program based on community activities and instruments which supported the GC program based on community. Therefore, the research team provided socializations and trainings on the GC program based on community which was needed by the counselor in the real situation.

It was a very important study because there were few researches trying to develop a GC Program based on Community within the framework of community counselors and to enforce accountability. Few experts attempt to design research to assess the effectiveness of comprehensive counseling programs [11]. The research on the impact of counseling services was used to be experimental strategies so the understanding of the services impact focused on a single service. Whereas; the praxis need of counseling services outside school or community settings was a model of program development which could provide information on the impacts of guidance and counseling services. It happened also in Indonesia, where few researches were specifically directed to develop the GC program based on community.

Based on the results of those limited trials, it showed that the practitioners' responses as the community counselors at Semarang toward the model of GC program based on community was effective to improve the community counselors in providing GC services based on community. It allowed the community counselors to know the upto-date status of counseling guidance management services they performed at community settings.

If the effectiveness of a program was linked to its accountability, it was understandable that the results of a program development strongly supported the accountability enforcement. When the evaluation results were very accurate, the counselor could uphold the accountability on counseling and guidance services by demonstrating the performance and impact of counseling and guidance services provided [8]. Thus; the community counselors could accurately state the importance of the counseling profession at the communities. The follow-up results of the CG program based on community would enable the community counselor to perform optimally. Consequently, the community counselors could make decisions about changes which should be made to improve the quality of counseling and guidance services at community settings.

\section{CONCLUSION}

Based on the discussion above, it can concluded that the model of a GC Program based on 
Community on the setting of guidance and counseling services outside the school was needed by the community counselors. Thus, it is expected that the model development of a GC Program based on Community is ready to be used to improve the quality of guidance and counseling services at the community settings.

Then, it is suggested that the researchers to describe the operational research stages in detailed so the model is more applicable and easy to be understood, In addition, community counselors to develop a GC Program based on Community which is appropriate to the needs for providing the optimum GC services.

\section{REFERENCES}

[1] Cobia, D.C., \& Handerson, D.A. (2003). Handbook of School Counseling. Upper Saddle River: Merrill Prentice Hall.

[2] Cobia, D.C., \& Handerson, D.A. (2007). Developing an Effective and Accountable School Counseling Program. Upper Saddle River: Merrill Prentice Hall.

[3] Sugiyo dan Muslikah. (2014). Pengembangan Model Evaluasi Pelayanan Bimbingan dan Konseling di Sekolah Menengah Atas (SMA) Berbasis CIPP. Laporan Penelitian Terapan.

[4] Depdiknas. (2005). Panduan Pengembangan Diri. Jakarta: Depdiknas.

[5] Depdiknas. (2007). Rambu-rambu Penyelenggaraan Bimbingan dan Konseling dalam Jalur Pendidikan Formal. Bandung: Jurusan PPB FIP UPI.

[6] Gysbers, N.C. (1995). Evaluating School Guidance Program. ERIC Digest. ED388887.
[7] Gysbers, N.C., \& Handerson, P. (2006). Developing and Managing Your School Guidance and Counseling Program. Alexandria: American Counseling Association.

[8] Sink, C.A. (2009). School Counselors as Accountability Leaders: Another Call For Action. Professional School Counseling. (online) Diunduh melalui www.findarticles.com pada tanggal 30 September 2010.

[9] Brown, Duane \& Trusty; (2005); Designing and Leading Comprehensive School Counseling Program, Promoting Studentas and Meeting Students Needs, Australia Thomson.

[10] Sugiyo. (2010). Faktor-faktor yang Berkontribusi terhadap Kepuasan Kerja dan Kinerja Konselor (Guru Pembimbing) di Sekolah. Pidato Pengukuhan Guru Besar Jurusan Bimbingan dan Konseling FIP Universitas Negeri Semarang, Semarang, 23 Februari 2010.

[11] Brown, D., \& Trusty, J. 2005. The ASCA National Instrumen, Accountability, and Establishing Causal Links between School Counselors' Activities and Student Outcomes: A Reply To Sink. Professional School Counseling. (online) Diunduh melalui www.findarticles.com pada tanggal 30 September 2010.

[12] Borg \& Gall; (2007); Educational Research, An Introduction, Boston, Pearson Internasional Edition

[13] Mills M.B dan Hubermen, MD. (1984). Qualitatif Data Analysis: A Sources of New Method, Beverly Hills; Sage Edition. 